\title{
A review of scarab beetles (Coleoptera: Scarabaeidae) diversity in India
}

\author{
C. Zothansanga \\ Department of Life Sciences, Pachhunga University College, Mizoram University, Aizawl 796001, India
}

\begin{abstract}
The diversified geographic location along with climatic conditions has led to the enrichment of fauna species in India. Coleoptera (Gk. Coleos-sheath, ptera-wing) are the largest group of organisms at the order level and are comprised of beetles. They adapt to a wide range of environmental conditions and are widely distributed. The family Scarabaeidae which is included in the superfamily Scarabaeoidea is one of the largest families. They consist of about 27,800 species worldwide and are further divided into 16 subfamilies, 82 tribes and 94 sub-tribes. They are usually harmful or beneficial in nature with their size being large to small. The research on scarab beetles is necessary to understand their role as pest as well as their adaptation to different anthropogenic activities. Also, the diversified population of scarab beetles along with their similar characters makes it hard for researchers to identify them often leading to misidentification which is why a review is needed. This review summarizes the status, diversity and ecological status of scarab beetles in India.
\end{abstract}

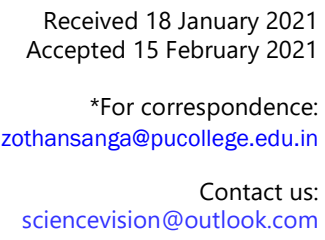

Keywords: Beetle, coleoptera, diversity, scarabaeidae, India.

\section{Introduction}

India has a diversified climatic condition and its unique biogeographic location has led to a richness in terms of biological diversity. About $6.90 \%$ of the total number of species of Phylum Arthropoda belongs to India of which 59,393 species belong to class Insecta. Coleoptera (Gk. Coleos-sheath, pterawing) are the largest group of organisms at the order level and are comprised of Beetles. They are cosmopolitan in distribution and show a wide range of adaptations to environmental conditions. ${ }^{1}$ Coleoptera consists of about $3,50,000$ of the $8,00,000$ described insect species which belongs to 4 sub-orders and 177 families. ${ }^{2}$ The forewings of Coleoptera are adapted into defensive covers or 'elytra', their size usually ranges from minute to large insect with prominent compound eyes. ${ }^{3}$ They play an important role in the terrestrial ecosystem and further studies are required to know their activity in various avian food chains along with anthropogenic activities, vegetation, soil and other biological indicators. ${ }^{1}$

The family Scarabaeidae Latrielle, 1802 under the order coleoptera is composed of about $91 \%$ of all the scarabaeoids and is the richest family under the superfamily Scarabaeoidea and consists of about 27,800 species worldwide. ${ }^{4}$ They are further divided into 16 subfamilies, 82 tribes and 94 sub tribes. ${ }^{5} 1590$ species under 203 genera are known in India. They 


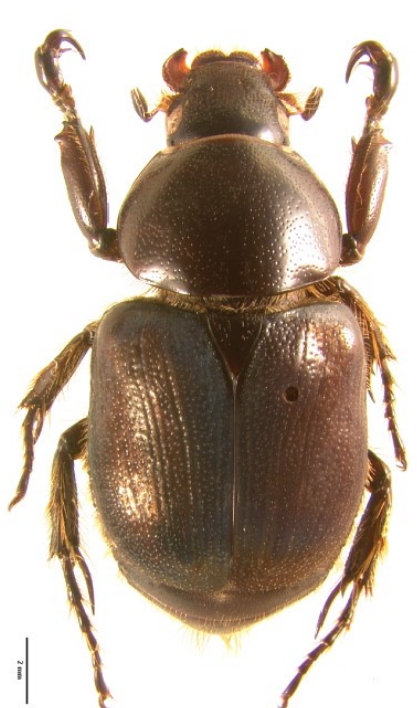

1 Peltonotus animus, male

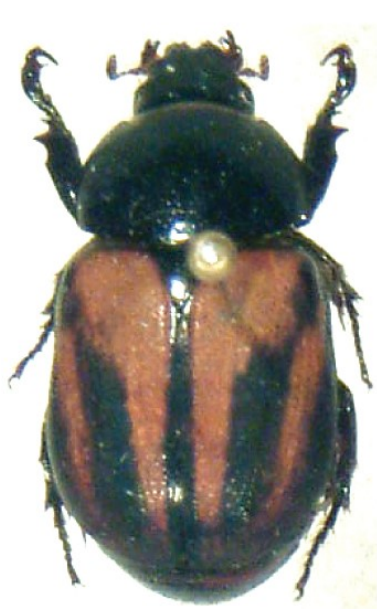

5 Peltonotus fujiokai, male

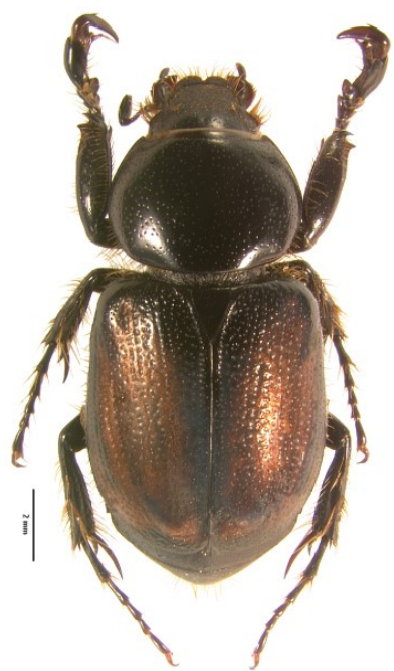

9 Peltonotus karubei, male

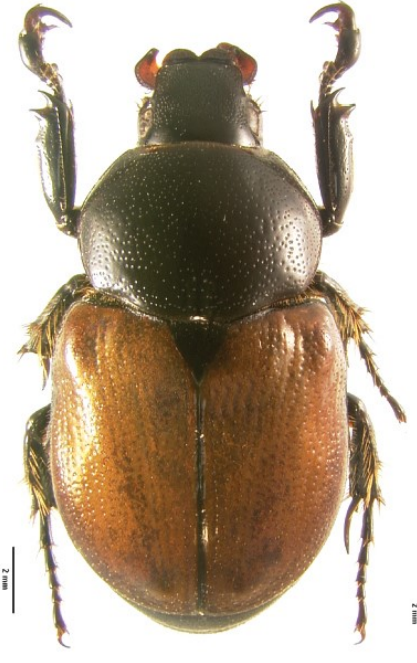

2 Peltonotus cybele, male

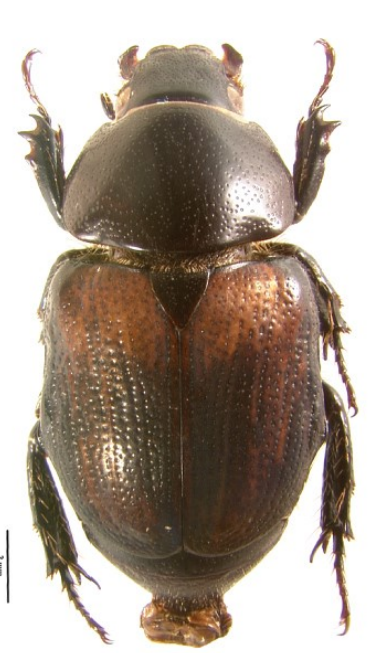

3 Peltonotus cybele, female

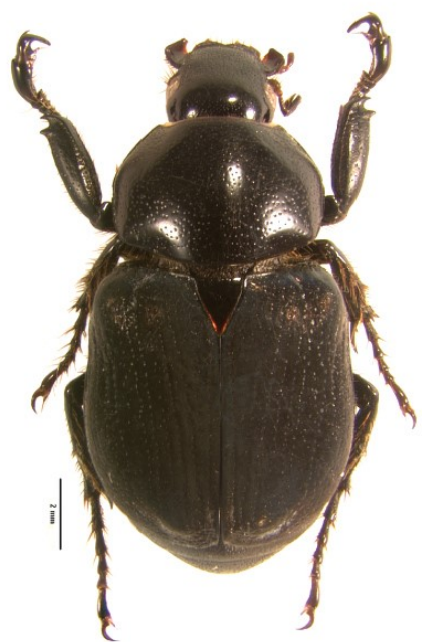

4 Peltonotus favonius, male

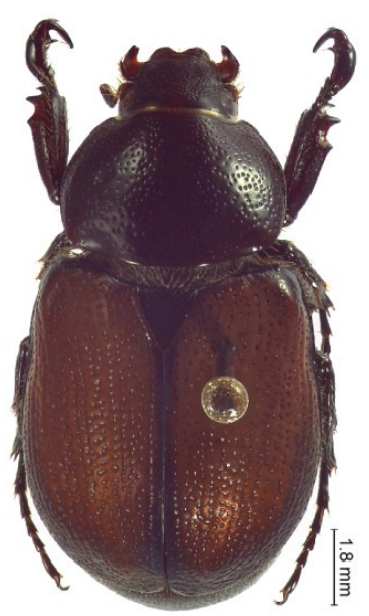

6 Peltonotus fujiokai, male

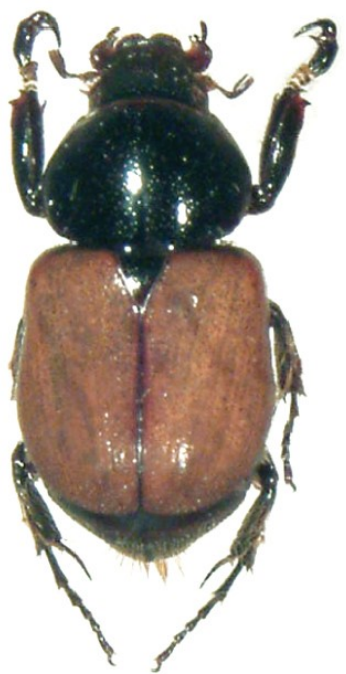

10 Peltonotus malayensis, male

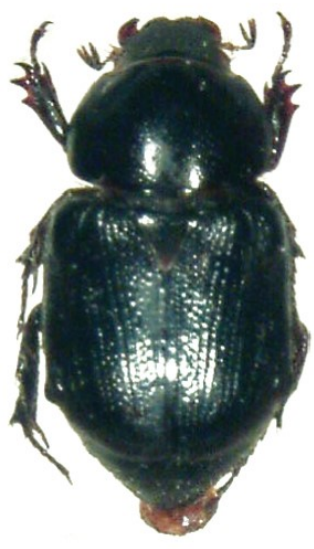

11 Peltonotus malayensis, female

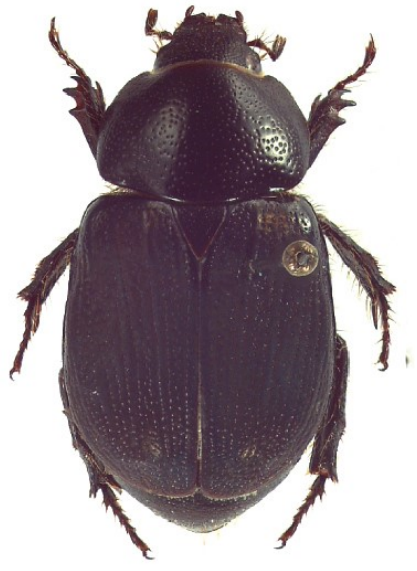

8 Peltonotus fujiokai, female

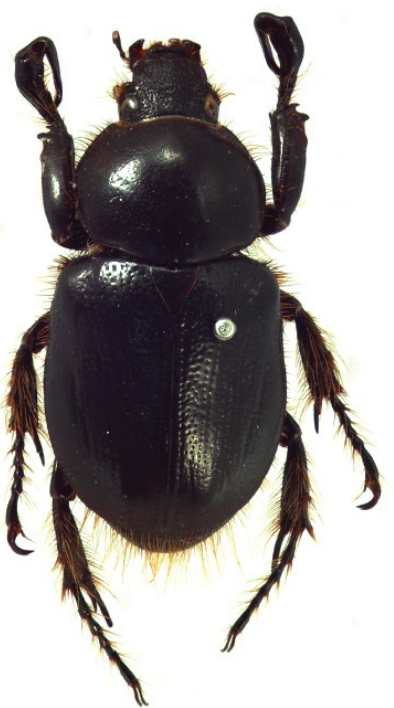

12 Peltonotus morio, male

Figure 1 | Some scarab beetles. Jameson and Drumont (2013), ZooKeys 320: 63-95. doi: 10.3897/zookeys.320.5352 CC-BY SA 3.0). 
are usually small to large in size and are easily recognized by the shape of their antennae. They are a serious pest of forestry, agriculture and some fruit trees and they are economically important. Scarab family are usually beneficial or harmful in nature. ${ }^{6}$ The subfamily Scarabaeinae are called dung beetles and are beneficial, they are coprophagous and feed on dung and carrion. They play an important role in nutrient cycling and also decrease flies present in dung along with parasitic worms. The other subfamilies like Rutelinae, Dynastinae, Melolonthinae and Caetoniinae are called chafers, they are phytophagous and harmful and usually feed on various commercial crops acting as pests. ${ }^{4}$ They constitute about three fourth of the beetle species and harmful both in the larval and adult stage. ${ }^{7}$

The difference in vegetation, soil, altitude along with the crops grown has influenced the diversity of beetles. $^{8}$ The decrease in dung due to the decrease in the number of cattle, habitat loss, environmental changes, increase human interference, use of antibiotics and loss of food quality due to pollutants has led to the decrease in the diversity of dung beetles. $^{4}$ The variation in climatic conditions along with different parameters such as wind speed, rainfall, humidity, moisture and temperature has a great influence on the diversity of these scarab beetles. ${ }^{9}$ The diversity along with its ecology and biology is of great interest because of their economic importance, their role in the ecosystem, forest biodiversity as well as their grubs and larvae serving as food in some insectivorous bird food chain. $^{10}$

\section{India}

Due to the different geographic regions along with the variation in latitude and altitude, scarab beetles are present in different parts of India. The diversity of Indian beetles was first known when Leroy published his work named Indian Insect life in 1909. ${ }^{11}$ Later in 1931, Arrow mentioned his work on Indian Coprinae under the series Fauna of British India. ${ }^{12}$ Balthasar then later published his work on Scarabaeidae of the Oriental and Palaearctic region. ${ }^{13}$ The report on the diversity of Scarabaeidae in different Indian states viz. West Bengal, Arunachal Pradesh, Delhi, Tripura, Manipur, Sikkim, Meghalaya and North East India was carried out by Biswas. ${ }^{14-18}$ In 1985 and 1986, the diversity of dung beetles from Gujarat and Rajasthan was reported by Sewak. ${ }^{19-20}$ Sewak also studied dung beetles from five districts of western Uttar Pradesh. ${ }^{21}$ The different types of dung beetles from Bangalore and different parts of Karnataka was studied by Veenakumari and Veeresh. ${ }^{22}$ They also studied three species of Scarabaeinae from Bangalore in the following year. ${ }^{23}$ Chattarjee and Biswas also made notable contributions. $^{24}$ In 2000, Chattarjee and Biswas reported the fauna of Scarabaeidae: Coprinae from two North East states viz. Tripura and Meghalaya. ${ }^{25}$ Mittal reported the presence of about 30,000 species of scarabaeid beetles from India. ${ }^{26}$ Sewak also published his work on the fauna of Scarabaeidae: Coprinae from Gujarat. ${ }^{27}$ Singh and his co-workers studied the distribution of white grub fauna in Garhwal hills of western Himalaya. ${ }^{28}$ The Scarabaeidae: Coprinae fauna of Thar desert, Rajasthan and Arunachal Pradesh were studied by Sewak. He reported the presence of 73 species of laparostict scarabs belonging to 14 genera from Arunachal Pradesh with no records on pleurostict scarabs. ${ }^{29-30}$ However in 2012, Chandra and Gupta reported 12 species of pleurostict scarabs from Arunachal Pradesh. ${ }^{31}$ They also reported 43 species of scarab beetles belonging to 25 genera, 16 tribes and eight subfamilies in two families from Chhattisgarh, India in which 31 species are new to the scarab fauna. ${ }^{32}$

Chandra reported the presence of 2,500 species of scarabeid beetles from India with most of them being phytophagous leaf and fruit feeders. He reported the diversity of scarabaeid beetles from Madhya Pradesh which consists of 94 taxa belonging to 9 subfamilies. ${ }^{33}$ The scarabid beetles of Pench Tiger Reserve (Seoni), Madhya Pradesh was also studied by Chandra. ${ }^{34}$ The Scarabaeid beetles of Bandhavgarh National Park and Kanha Tiger Reserve, Madhya Pradesh was studied by Chandra and Ahirwar. They revealed 44 species belonging to 24 genera and 8 subfamilies from Bandhavgarh National Park and a total of 61 species of Scarabaeidae beetles belonging to 27 genera under 8 subfamilies from Kanha Tiger Reserve. They also report the fauna of Scarabaeidae family from Madhya Pradesh and Chattisgarh and recorded 124 species/subspecies belonging to 45 genera in 11 subfamilies. ${ }^{35-37}$ Singh et al. reported 12 species of the family Scarabaeidae from 70 species of beetles (Coleoptera) in Kane Wildlife Sanctuary from Arunachal Pradesh. ${ }^{38} 59$ species of scarabaeid beetles were collected in and around Amba Reserved forest of Western Ghat region Kolhapur district, Maharashtra by Aland et al. ${ }^{39}$

29 species of Scarabaeidae family was reported by Bhawane et al. with most of them being polyphagous and serious pest. ${ }^{40} \mathrm{He}$ also reported 26 species of dung beetles belonging to Scarabaeinae subfamily from Sindhudurg district, Maharashtra. ${ }^{41}$ David and Petr in 2013 also reported 29 species of beetles belonging to the family Scarabaeidae from the state of Rajasthan, Maharashtra and Goa. ${ }^{42} 61$ species of scarabaeoid beetles was updated and reported from Pench Tiger Reserve, Madhya Pradesh which belongs to 30 genera, 19 tribes, 3 families and 7 subfamilies. ${ }^{43}$ One species of genus Bolbogonium Boucomont, 1911 and 4 species of genus Bolbohamatum Krikken, 1980 from Central India was reported by Kailash Chandra and Devanshu Gupta. ${ }^{44}$ They also reported 52 scarab beetles belonging to 
24 genera and 5 subfamilies from AchanakmarAmarkantak Biosphere Reserve, Chhattisgarh. ${ }^{45} 22$ scarab species of beetles were also reported by Chandra and Singh from Achanakamar Wildlife Sanctuary, Chhattisgarh ${ }^{46}$ The diversity of scarab beetles from Govind Wildlife Sanctuary was reported by Chandra et al. which consists of 11 species belonging to 2 families of superfamily Scarabaeoidea. ${ }^{6} 53$ species, 27 genera and 6 subfamilies of scarab beetles from Sidhi district of Madhya Pradesh was reported by Chandra et al. ${ }^{47} 32$ species of scarab beetles were recorded from Melghat Tiger Reserve, Vidarbha, Maharashtra by Thakare et al. which belongs to 22 genera, 8 subfamilies and 3 families under superfamily Scarabaeoidea. ${ }^{3} 89$ species of scarabaeid beetle in 32 genera and 6 subfamilies were reported by Jadhav et al. from Maharashtra in 2012. In 2018, Khadakkar et al. reported the presence of 97 species of scarabaeidae family under 39 genera belonging to 7 subfamilies from Maharashtra taking into account the previous work done by Jadhav et al. ${ }^{48-49}$

In 2019, Aparna reported five new records of dung beetles from two subfamilies of scarabaeidae and the current scarab beetle diversity from Maharashtra stands at 102 species in 43 genera. ${ }^{50}$ Tom and Kaippallil reported a total of 51 species of Coleopterans from Kerala out of which 4 species belong to the scarabaeidae family. ${ }^{51}$ Thakkar and Parikh in 2016 reported 177 species of coleopteran beetles from Gujarat out of which 38 species belong to scarabaeidae family. ${ }^{52}$ Chandra and Gupta reported 669 beetles from Singhori Wildlife Sanctuary, Raisen, Madhya Pradesh representing 26 species of sacarabaeid beetles belonging to 12 genera and two subfamilies. They reported 24 species of the subfamily scarabaeinae. ${ }^{53} 10$ species of scarabaeid beetles belonging to 8 genera under 3 subfamilies was reported from Salt Lake City, Kolkata by Ghosh and Bhunia in $2016 .{ }^{54} \mathrm{~A}$ new species of scarab beetle Pukupuku Muramoto, 2006 was reported from Arunachal Pradesh in 2016 by Gupta et $a l^{55}$ In 2019, a new species Enoplotrupes tawangensis belonging to scarabaeidae family was again described by Gupta et al. from Arunachal Pradesh. ${ }^{56}$

An updated checklist of coleoptera diversity from Chattisgarh was reported by Gajendra and Prasad. They reported 194 species of beetles belonging to 6 families and 23 subfamilies with Scarabaeidae family consisting of 78 species belonging to 7 subfamilies. ${ }^{57}$ Bhattacharyya et al. studied the diversity and abundance of scarab beetles from Assam and reported 44 species of scarabs belonging to 6 subfamilies out of which 41 species are new records. $\mathrm{He}$ also mentioned that out of these 44 species, 5 are coprophagous while the other 39 species are phytophagous. ${ }^{58}$ Patole reported 15 species of scarabaeid beetles belonging to 14 genera in 5 subfamilies viz., Dynastinae, Scarabaeinae, Rutelinae,
Cetoniinae and Melolonthinae from Sakri, DistDhulia, Maharashtra. ${ }^{4}$ Thomas Latha and Thomas K. Sabu reported 34 species of scarab beetles belonging to 11 genera from Nelliampathi, South Western Ghats in 2018. They also provide pictorial keys for rapid and baseline identification of dung beetles. Onthophagus deflexicollis (Lansberge, 1883), O. manipurensis (Arrow, 1907) and Tibiodrepanussinicus (Harold, 1868) were found to be the first report from the South Indian region. ${ }^{59}$ Srinivasa surveyed the different agroecological regions of Western Ghats in Karnataka revealing the occurrence of 18 species of scarabaeid beetles. He reported that species richness was found to be negatively and significantly correlated with altitude and suggests that low temperature at high altitudes inhibit the development and growth of beetles. ${ }^{60}$ Venugopal et al. reported 519 dung beetles from the Malabar coast in southern India which represents 26 different species belonging to 8 genera and five tribes. An assessment on the community structure and diversity of dung beetles associated with semiurban agricultural land was also done by them which reveals that urbanization has affected the community structure and led to a decrease in the diversity of dung beetles as compared to regional forests. ${ }^{61}$

\section{Conclusion}

The diverse physical features along with different climatic conditions of India helps in sustaining and harboring high biodiversity. Beetles belong to the order coleoptera and are ubiquitous. The family scarabaeidae under coleoptera is the largest family of insects. This review was made to gather all the information on the diversity and ecological status of scarabaeidae in India. The diversity and its role in the different ecological systems were studied and explained by different authors. Reports have been made that the diversity of the scarab beetles have been significantly correlated with altitude which results in the inhibition of growth and development of these beetles. The coprophagous scarab beetles play an important role in nutrient cycling and some works have been done regarding their role in the ecosystem. However, the phytophagous scarab beetles as reported are more in number and they usually serve as pests during their larval as well as their adult stage. Further studies are still required to know their role in the ecosystem as well as their feeding behaviour in serving as pests to different crops, plants and fruits. Reports have also been made that the diversity of these scarab beetles are declining due to urbanization. However, scanty works are available to know the effects of urbanization regarding their diversity as well as their adaptation to anthropogenic activities. Therefore, the study and survey of scarabaeid beetles in India need to be considered due to their large impact on 
the biodiversity of India.

\section{References}

1. Kritika, T., \& Jaimala, S. (2017). Diversity and ecology of coleoptera in India: A review. Journal of Entomology and Zoology Studies 5(2), 1422-1429.

2. Alfred, J.R.B., Das A.K. \& Sanyal A.K. (1998). Faunal Diversity of India, ENVIS Centre, Zoological Survey of India, Calcutta, pp. 259-268.

3. Thakare, V., Zade, V., Chandra, K., \& Gupta, D. (2012). Scarab beetles (Coleoptera: Scarabaeoidea) of Melghat Tiger Reserve, Central India. Academic Journal of Entomology 5(2), 73-80.

4. Patole, S.S. (2019). Studies on diversity and relative abundance of dung beetles (Coleoptera: Scarabaeidae) from Sakri Tahsil, DistDhulia (MS) India. Indian Journal of Applied Research 9(10).

5. Smith, A.B. (2006). A review of the family-group names for the superfamily Scarabaeoidea (Coleoptera) with corrections to nomenclature and a current classification. The Coleopterists Bulletin $\mathbf{6 0}$, 144-204.

6. Chandra, K., Gupta, D., Uniyal, V.P., Bharadwaj, M., \& Sanyal, A.K. (2012). Studies on scarabaeid beetles (Coleoptera) of Govind wildlife sanctuary, Garhwal, Uttarakhand, India. Biological Forum-An International Journal 4, 48-54.

7. Gillott, C. (2005). The remaining endopterygote orders. Entomology, 297-351.

8. Chandel, R.S., Gupta, P.R., \& Chander, R. (1994). Diversity of scarabaeid beetles in mid hills of Himachal Pradesh. Himachal Journal of Agricultural Research 20(1\&2), 98-101.

9. Pal, S.K. (1977). Relative abundance of scarabaeid beetles on light trap. Indian Journal of Entomology 39, 197-200.

10. Aerts, R., \& Honnay, O. (2011). Forest restoration, biodiversity and ecosystem functioning. $B M C$ Ecology 11(1), 29.

11. Lefroy, H.M. (1909). Indian Insect Life (A Manual of the Insects of the Plains, Tropical India), W. Thacker and Co., 2 Creed Lane, London.

12. Arrow, G.J. (1931). Fauna of British India including Ceylon and Burma. Lamellicorniae part III (Coprinae). Taylor \& Francis, London, 428.

13. Balthasar V. Monographie der Scarabaeidae und Aphodiidae der Palaearktischen und Orientalischen Region (Coeoptera: Lamellicornia), Verlag der Tscheshoslowakischen Akademic der Wissenschften, Prague, pp. 196, 1-39.
14. Biswas, S. (1978). Studies on the scarab beetles (Coleoptera: Scarabaeidae) of North Eastern India: A new species and notes on other Indian species of subgenus Strandius, genus Onthophagus. Journal Bombay Natural History Society 75(3), 911-913.

15. Biswas, S. (1978). Studies on the scarab beetles (Coleoptera: Scarabaeidae) of North East India part II: Three new species and two new record from India. Journal Bombay Natural History Society 76, 339-344.

16. Biswas, S., \& Chatterjee, S.K. (1985). Insecta: Coleoptera: Scarabaeidae: Coprinae. Records of the Zoological Survey of India 82(1-4), 147-177.

17. Biswas, S., \& Chatterjee, S.K. (1985). Insecta: Coleoptera: Scarabaeidae: Cetoninae. Fauna of West Bengal, State Fauna Series 3(3), 363-447.

18. Biswas, S., Mukhopadhyaya., Saha, S.K., Basu, R.C., Chatterjee, S.K., Chakraborthy, S.K. et al. (1997). Insecta: Coleoptera: Scarabaeidae: Coprinae. Fauna of Delhi, State Fauna Series 6, 325353.

19. Sewak, R. (1985). On a collection of dung beetles (Coleoptera: Scarabaeidae: Coprinae) from Gujarat, India. Oikasay 2(2), 33-35.

20. Sewak, R. (1986). On a collection of dung beetles (Coleoptera: Scarabaeidae: Coprinae) from Rajasthan, India. Oikasay 3(1), 11-15.

21. Sewak, R. (1991). Dung beetles (Coleoptera: Scarabaeidae: Coprinae) from five districts of western Uttar Pradesh. Oikasay 8(1/2), 25-27.

22. Veenakumari, K., \& Veeresh, G.K. (1997). Dung beetle (Coleoptera: Scarabaeidae: Scarabaeinae) fauna of Bangalore, Karnataka. Journal Bombay Natural History Society 94, 171-172.

23. Veenakumari, K., \& Veeresh, G.K. (1998). Nidification of three species of Scarabaeinae (Coleoptera: Scarabaeidae) in Bangalore. Journal Bombay Natural History Society 95(2), 358-369.

24. Chatterjee, S.K., \& Biswas, S. (2000). Coleoptera: Scarabaeidae, Cetoniinae, Dynastinae, Rutelinae. Zoological Survey India, State Fauna Series 4(5), 161-199.

25. Chatterjee, S.K., \& Biswas. S. (2000). Insecta: Coleoptera: Scarabaeidae: Coprinae. Zoological Survey of India, Fauna of Meghalaya, State Fauna Series 4(5), 513-526.

26. Mittal, I.C. (1999). Annotated list of scarab fauna (Scarabaeidae: Coleoptera) of western Uttar Pradesh (India). Annals of Entomology 17(2), 25-43.

27. Sewak. R., (2004). Insecta: Coleoptera: Scarabaeidae: Coprinae (Dung Beetles). Fauna of 
Gujarat, State Fauna Series 8(2), 105-125.

28. Singh, M.P., Bisht, R.S., \& Mishra, P.N. (2003). Distribution of white grub fauna in Garhwal hills of western Himalayas. Indian journal of entomology 65(2), 217-221.

29. Sewak, R. (2005). Dung beetles (Coleoptera: Scarabaeidae: Coprinae) of Thar Desert of Rajasthan. Changing faunal ecology in the Thar Desert. Scientific, Jodhpur. 143-148.

30. Sewak, R. (2006). Insecta: Coleoptera: Scarabaeidae: Coprinae (Dung Beetles). Fauna of Arunachal Pradesh. Part 2, Invertebrates. State Fauna Series, 191-224.

31. Chandra, K., \& Gupta, D. (2012). Pleurostict scarabs (Coleoptera: Scarabaeidae): new distributional records in Arunachal Pradesh, North-East India. Check List 8(5), 889-893.

32. Chandra, K., \& Gupta, D. (2013). Scarab beetles (Coleoptera: Scarabaeoidea) of Barnawapara Wildlife Sanctuary, Chhattisgarh, India. Journal of Threatened Taxa 5(12), 4660-4671.

33. Chandra, K. (2000). Inventory of scarabaeid beetles (Coleoptera) from Madhya Pradesh, India. Zoo's Print Journal 15(11), 359-362.

34. Chandra, K. (2002). On a collection of Scarabaeid beetles from Pench Tiger Reserve (Seoni, Madhya Pradesh). Journal of Tropical Forestry 18(2-3), 104 107.

35. Chandra, K., \& Ahirwar, S.C. (2005). Scarabaeid beetles of Bandhavgarh national park, Madhya Pradesh. Zoos' Print Journal 20(8), 1961-1964.

36. Chandra, K., \& Ahirwar, S.C. (2005). Scarabaeid beetles (Coleoptera) of Kanha Tiger Reserve, Madhya Pradesh. Records of the Zoological Survey of India 105(1-2), 147-155.

37. Chandra, K.A.I.L.A.S.H., \& Ahirwar, S.C. (2007). Insecta: Coleoptera: Scarabaeidae. Fauna of Madhya Pradesh (including Chhattisgarh), State Fauna Series 15, 273-300.

38. Singh, O.T., Chakravorty, J., \& Varatharajan, R. (2010). Entomofauna of Kane Wildlife Sanctuary, Arunachal Pradesh, Northeastern India. Journal of Threatened Taxa 2, 1392-1400.

39. Aland, S.R., Mamlayya, A.B., \& Bhawane, G.P. (2012). Diversity of scarabaeid beetles (Coleoptera: Scarabaeidae) in and around Amba reserved forest of western ghat region Kolhapur district, Maharashtra. Indian Journal of Tropical Biodiversity 20(1), 84-87.

40. Bhawane, G.P., Mamlayya, A.B., Wagh, S.R., \& Chaugule, A.K. (2012). Diversity of white grub beetles and their host range from northern Western Ghats, Kolhapur District (MS) India. The Bioscan 7(4), 589-596.

41. Bharamal, D.L., Koli, Y.J., Korgaonkar, D.S., \& Bhawane, G.P. (2014). Scarab (Scarabaeidae) fauna of Sindhudurg District, Maharashtra, India. Biolife 2(4), 1301-1304.

42. Kral, D., \& ŠÍPEK, P. (2013). Aphodiinae (Coleoptera: Scarabaeidae) of the Goa, Maharashtra and Rajasthan (India) with description of Aphodius (Gilletianus) rajawatorum sp. nov. Acta Entomologica Musei nationalis Pragae 53(2), 633-648.

43. Gupta, D., Chandra, K., and Khan. S. (2014). An updated checklist of scarabaeoid beetles (Coleoptera: Scarabaeoidea) of Pench Tiger Reserve, Madhya Pradesh, India. Journal of Entomology and Zoology Studies 2(5), 225-240.

44. Chandra, K., \& Gupta, D. (2012). Bolboceratine scarabs of genera Bolbohamatum Krikken, 1980 and Bolbogonium Boucomont, 1911 (Coleoptera: Geotrupidae) from central India. TAPROBANICA: The Journal of Asian Biodiversity 4(2), 69-76.

45. Chandra, K., \& Gupta, D. (2012). An inventory of scarab beetles (Coleoptera: Scarabaeidae) of Achanakmar-Amarkantak biosphere reserve, Chhattisgarh, India. International Journal of Science and Nature 3(4), 886-891.

46. Kailash, C., \& Singh, S.P. (2010). Scarabaeid beetles (Coleoptera) of Achanakmar Wildlife Sanctuary, Chhattisgarh. National Journal of Life Sciences 7(1), 71-74.

47. Kailash, C., Gupta, D., \& Goel. S.C. (2015). On Scarab beetles (Coleoptera: Scarabaeidae) from Sidhi district of Madhya Pradesh, India. Uttar Pradesh Journal of Zoology 35(3): 235-243.

48. Jadhav M.J., \& Sharma. R.M. (2012). Insecta: Coleoptera: Scarabaeidae Scarabaeid beetles. Fauna of Maharashtra, State Fauna Series 20(2), 489-494.

49. Khadakkar, S.S., Tiple, A.D., \& Khurad, A.M. (2019). Scarab Beetles (Coleoptera: Scarabaeoidea: Scarabaeidae) of Vidarbha, India, with Notes on Distribution. Proceedings of the National Academy of Sciences, India Section B: Biological Sciences 89(4), 1239-1249.

50. Kalawate, A.S. (2019). Some new distributional records of scarabaeid beetles from Maharashtra. Journal of Entomology and Zoology Studies 7(1), 727729.

51. Tom, H., \& Kaippallil, J.D. (2016). A preliminary study on the diversity of coleopterans in a rural area in Changanacherry, Kerala. Journal of 
Entomology and Zoology Studies 4(5), 297-300.

52. Thakkar, B., \& Parikh, P.H. (2016). A Study on diversity and abundance of coleopterans in Gujarat, India. Journal of Entomology and Zoology Studies 4(5), 1082-1089.

53. Chandra, K., \& Gupta, D. (2012). Diversity and composition of dung bettles (scarabaeidae: scarabaeinae and aphodiinae) assemblages in singhori wildlife sanctuary, raisen, madhya pradesh (India). Munis Entomology and Zoology Journal 7, 1-16.

54. Ghosh, B., \& Bhunia, D. (2016). Scarab beetle (Coleoptera: Scarabaeidae) from Salt Lake City, Kolkata, West Bengal. Journal of Entomology and Zoology Studies 4(1), 269-273.

55. Gupta, D., \& Bezděk, A. (2017). Pukupuku arunachalensis Sp. Nov. (Coleoptera, Scarabaeidae, Rutilinae) from Arunachal Pradesh, India. European Journal of Taxonomy 257, 1-11.

56. Gupta, D., Chandra, K., Král, D., Ghosh, J., \& Das, P. (2020). Enoplotrupes (Enoplotrupes) tawangensis sp. nov.(Coleoptera: Geotrupidae) from Arunachal Pradesh (India) and Bhutan, along with a key to its relatives. Oriental Insects 54(3), 299 -307 .
57. Gajendra, N., \& Prasad, S.K. (2016). A Review of Coleoptera diversity of Chhattisgarh: updated checklist 2015. International Journal of Science and Research 5(4), 710-714.

58. Bhattacharyya, B., Handique, G., Pujari, D., Bhagawati, S., Mishra, H., Gogoi, D., \& Debnath, H. (2017). Species diversity and relative abundance of scarab beetle fauna in Assam, Northeast India. Journal of Entomology and Zoology Studies 5(1), 711-716.

59. Latha, T., \& Sabu, T.K. (2018). Species list with pictorial key for dung beetles (Coleoptera: Scarabaeidae: scarabaeinae) of Nelliampathi in South Western Ghats, India. International Journal of Current Advanced Research 7, 16121-16128.

60. Kotilingam, S.M. (2020). Assessment Scarabaeid Beetle Diversity in Various Cropping Regions of Karnataka. Entomology Ornithology \& Herpetology 9, $1-4$.

61. Venugopal, K.S., Thomas, S.K., \& Flemming, A.T. (2012). Diversity and community structure of dung beetles (Coleoptera: Scarabaeinae) associated with semi-urban fragmented agricultural land in the Malabar coast in southern India. Journal of Threatened Taxa 4(7), 2685-2692. 